\title{
Raising Academic Standards and Vocational Concentrators: Are They Better Off Or Worse Off?
}

\author{
John H. Bishop
}

Ferran Mane

Working Paper 04 - 12 


\title{
Raising Academic Standards
}

\section{and Vocational Concentrators:}

\section{Are They Better Off Or Worse Off?}

\author{
John H. Bishop \\ Human Resources Studies Department \\ 390 Ives Hall \\ School of Industrial and Labor Relations \\ Cornell University \\ Ithaca New York 14853, USA \\ Tel: + 16072571402 \\ e-mail: jhb5@cornell.edu \\ Ferran Mane \\ Universitat Rovira i Virgili \\ Departament d'Economia \\ Av. de la Universitat, 1 \\ 43202 Reus, Catalunya, Spain \\ Tel: +34 977759847 \\ fmv@fcee.urv.es
}

July 2004

http://www.ilr.cornell.edu/cahrs

This paper has not undergone formal review or approval of the faculty of the ILR School. It is intended to make results of Center research available to others interested in preliminary form to encourage discussion and suggestions.

Most (if not all) of the CAHRS Working Papers are available for reading at the Catherwood Library. For information on what's available link to the Cornell Library Catalog: http://catalog.library.cornell.edu if you wish. 


\begin{abstract}
This paper measures the impacts of tougher graduation requirements on course taking patterns, learning, college attendance and post high school labor market outcomes for vocational concentrators and non-concentrators. Our main goal was to assess whether vocational education students were specifically affected (positively or negatively) by the policies heavy emphasis on the academic part of the high school curriculum. Our results show how requiring higher number of academic credits to graduate and introducing a Minimum Competency Exams help high school graduates to be more successful in the labor market, but reduce their chances of obtaining a college degree. Vocational concentrators are better off in MCE states. The positive signal they sent to employers reinforces the occupational skills vocational concentrators possess.
\end{abstract}

Keywords: graduation requirements, education standards, minimum competency exams, exit exams, career-tech, vocational education, curriculum effects on labor market outcomes.

\title{
Acknowledgements
}

F. Mane gratefully acknowledges financial support by the Spanish Ministry of Education. The authors would like to thank two anonymous referees for their helpful comments. 


\section{Raising Academic Standards And Vocational Concentrators: Are They Better Off Or Worse Off?}

\section{Introduction}

A series of commission reports during the 1980 s and early $1990 s^{1}$ warned of the economic consequences of shortcomings in the education of young Americans ${ }^{2}$. Two key problems were identified: weak incentives to take rigorous courses and to study hard caused by poor signalling of student achievements to universities and to employers ${ }^{3}$; and second, an unfocused curriculum that gave insufficient emphasis to core academic subjects. Concerned about the low standards and the proliferation of non-academic courses, many state departments of education have raised standards for graduating from high school ${ }^{4}$. Two of the most popular policy changes have been increasing the number of academic courses required to graduate from high school and requiring students to pass Minimum Competency Exams (MCE). ${ }^{5}$

To receive a high school diploma in the United States students must take and get passing marks in a minimum number (varying from state to state) of full-year full-time courses. ${ }^{6}$ The National Commission on Excellence in Education recommended in 1983 that all high school students take at least three full year courses (credits) each in mathematics, science and social studies and four credits of English. This recommendation represented a major departure from customary course taking patterns at that time. Only 14 percent of high school graduates in 1982 had completed the package recommended by the Commission. A lot has changed since then. Most states have increased the number of mathematics, science and social studies courses required to graduate. Seventeen states now require students to take the thirteen core academic courses recommended by the Commission. These changes appear to have succeeded in increasing academic course taking. Credits earned in algebra, geometry and higher-level math courses have increased 57 percent and the number of science courses taken has increased 42 percent. The total number of academic courses taken by typical high school graduates has increased by 31 percent: from 12.9 credits in 1982 to 16.9 credits in 2000 . 
The logic of a Minimum Competency Exam is to define standards for learning (what all students are expected to know), test students against these standards, and require that students pass exams assessing the achievement of these standards before graduating. MCEs are a set of exams that evaluate students in mathematics and reading and in some states also in writing and science. They are set up individually by every state (equal for all schools within the state, but of varying rigor across states). MCEs do not signal a student's achievement level in the subject, but just whether a student exceeds or falls below a specific cut point that all high school graduates are required to pass. Students usually take the exams in $10^{\text {th }}, 11^{\text {th }}$ or $12^{\text {th }}$ grade $^{7}$ and those who fail the first time are given $2^{\text {nd }}, 3^{\text {rd }}$ and $4^{\text {th }}$ chances to pass ${ }^{8}$. Public school students who accumulate the required number of course credits but fail to pass the MCE are typically awarded certificates of completion or special education diplomas.

MCEs produce two effects ${ }^{9}$ : first, there is the signalling effect that labels students as either a paser or a failer. Categorizing high school completers in this way makes it easier for employers to choose the right worker and should raise the wage offered students who pass the MCE and receive the standard diploma. Second, there should be a learning effect. The big increase in the rewards for learning in high school should induce teachers and administrators to raise academic standards and students to study harder. In 1992 fifteen states were awarding high school diplomas only to students who passed an MCE.

These two policies are clearly intended to force all high school students to develop a stronger background in academic subjects. This reflects a belief that all high school graduates now need greater skills in reading, writing, mathematics and science than in the past (Murnane et al, 1995; Murnane \& Levy, 1996; Murnane et al, 2000). A stronger academic background is presumed necessary to successfully deal with the changes brought about by technological progress, computers, management innovations and global competition. Turnover rates and rates of skill obsolescence are higher, so some question the value of teaching "narrow" occupation specific skills to teenagers. Some have indeed argued that responsibility for occupation specific skill development should be given to employers and post-secondary institutions not high schools. 
It is important to recognize, however, that at least 40 percent of youth seek full-time work immediately after high school and never complete even a single year of post-secondary education. For these students high school is going to be their last chance to develop occupational skills that can help them compete for good jobs. Facing high rates of job turnover, employers are not willing to hire neophytes and teach them how to repair automobiles or how to build a house. They prefer to hire workers who have been trained at a school or by a previous employer and they pay extra for the privilege. As a result, non-college bound students who take a program of four occupation-specific vocational courses (while reducing other courses by three) increase their earnings by $\$ 1675$ or about $20 \%$ in the year after high school graduation and by $\$ 1793$ seven years later. Even college completers benefit substantially from their high school vocational education (Bishop and Mane 2004). Other studies (Campbell et al, 1986, 1987; Mane, 1999) employing longitudinal data also conclude that the payoff to vocational courses rose considerably during the 1980 s and has stayed high.

This implies that requiring students to devote extra time to developing academic skills may, if it prevents them from taking vocational courses, lower the life time earnings of those who do not want to go to college. We therefore need to know whether tougher graduation requirements reduce vocational course taking and by how much. We also want to test the hypothesis that vocational students are uniquely responsive to these policies.

Three different policies are assessed: (1) state defined minimums for the total number of courses students must take and pass to get a high school diploma; (2) state defined minimums for the number of academic courses necessary to get a diploma and (3) minimum competency graduation tests.

The paper begins (in section 3) by assessing the impacts of tougher graduation requirements on vocational course taking and on the number of students who pursue a vocational specialty in high school. We find that MCEs have tended to reduce vocational course taking and lowered the proportion of students becoming vocational concentrators. Increased course graduation requirements, by contrast, do not appear to have decreased vocational 
course taking. Indeed, students in states with above average minimum credits to graduate take more vocational education courses than students in states with low minimums.

The rest of the paper (sections 4 and 5) is devoted to measuring the impacts of tougher graduation requirements on learning, college attendance and post high school labor market outcomes for vocational concentrators and non-concentrators. The results show that graduates educated in states with high total course graduation requirements do not learn more during high school, do not earn more after high school and are less likely to go to and complete college. In addition, Lillard and DeCicca (2001) found that dropout rates go up when the total number of courses required to graduate increase.

Increases in academic course requirements, the second policy, increase academic course taking, learning, wage rates and earnings but not college attendance or completion. The labor market effects for vocational concentrators in the short run are quite similar to the effects for others students, but they are worse in the medium run. Vocational concentrators are also worse off than their non-vocational peers in terms of college enrolment and completion. All in all, we don't find support for the hypothesis that increasing academic course requirements yield larger benefits for vocational than for non-vocational students.

Minimum competency exams increase academic course taking, learning, wages and earnings, but slightly reduce college attendance and completion. In this case, we do find rather conclusive support for the hypothesis that the positive MCE effects are larger for vocational concentrators, in the short and in the long run, than for non-vocational (with the exception of the learning variable).

In the last section of the paper we summarize the main findings and we suggest some policy implications of the results obtained.

\section{The data}

Our study makes use of micro data from the National Educational Longitudinal Study (NELS-88), a longitudinal data set that followed a nationally representative sample of $8^{\text {th }}$ graders in 1988 through the year 1992. In addition, two post-high school follow-ups were conducted, the 
first in 1994 (two years after scheduled graduation) and the second in 2000 (eight years after graduation). Information used in this paper comes from the student, school and family questionnaires. We studied the subset of NELS-88 high school graduates who were in public schools in $10^{\text {th }}$ grade and earned between 15 and 32 credits during high school.

We used the restricted data set that identifies the state in which the student's high school was located. This allows us to merge information on state policies and characteristics into the data set. Two variables were defined characterizing course graduation requirements: the first one is a dummy variable with a value of 1 for states with minimum competency exam graduation requirements in 1992 (Alabama, Florida, Georgia, Hawaii, Louisiana, Maryland, Mississippi, Nevada, New Mexico, New Jersey, New York, North Carolina, South Carolina, Tennessee, and Texas) and zero elsewhere ${ }^{10}$. Thirty-six percent of our sample lived in states that mandate the MCE and set the graduation standard on the exam.

The second variable measures the number of core academic courses (English, math, science and social studies) required to get a diploma. We also included a measure of the total number of credits the state required to get a diploma because this policy would also be expected to affect patterns of students' course taking and drop out rates ${ }^{11}$.

An important variable in our models is the exact number and types of courses the student took in high school. This information was obtained by collecting and coding each student's high school transcript which has been made available to researchers as part of the restricted file of the NELS-88 data set. We classified all courses into three major categories: vocational, academic and "personal interest" courses. ${ }^{12}$ Academic courses include English, foreign languages, mathematics, science, history, government and economics. The vocational course category was further subdivided into: (1) introductory vocational (industrial arts, introduction to technology and home economics); (2) occupational vocational (construction, business, health occupations, etc) ; and (3) computer related courses. Thus we separate introductory vocational courses intended for career exploration taken in the first two years of upper-secondary school from the more advanced and demanding courses that focus on a specific occupational cluster that are generally taken in the 
final two years of high school. Computer courses were considered vocational courses because they develop professional skills and are typically taught by vocational teachers. A separate computer category is defined because we expect them to have different effects on college and labor market outcomes and because the National Commission of Excellence in Education recommended that all students take at least a one semester long course in computer skills. We also derived from the transcript data the variable "vocational concentrator", which takes 1 if the student took 3 or more courses in a specific occupational field. ${ }^{13}$ This cut off point is the recommended by the National Assessment of Vocational Education. Only 14 percent of high school graduates in our data set meet the criteria for being a vocational concentrator.

Since the outcomes studied are primarily determined by the student's background and environment, we control for as many characteristics of the community and the student as possible in order to increase efficiency and reduce omitted variable bias. ${ }^{14}$

\section{Effects of graduation requirements on course taking patterns}

What has been the effect of high school graduation tests, academic course graduation requirements and total course graduation requirements on the number of vocational courses taken by high school students and the proportion of high school graduates who complete a vocational concentration? The results of regressing high school course taking patterns (number of courses taken in different fields) on indicators of student achievement in $8^{\text {th }}$ grade, a host of student background factors, school characteristics and the state's graduation requirements is given in Table 1. 
Table 1

Effect of Graduation Requirements on Courses Taken in High School

\begin{tabular}{|c|c|c|c|c|c|c|c|c|}
\hline & $\begin{array}{c}\text { Mean } \\
\text { (Standard } \\
\text { Deviation) }\end{array}$ & $\begin{array}{l}\text { State } \\
\text { Minimum } \\
\text { Comp } \\
\text { Exam }\end{array}$ & $\begin{array}{l}\text { Academic } \\
\text { Courses } \\
\text { Required } \\
\text { to Grad }\end{array}$ & $\begin{array}{l}\text { State } \\
\text { Minimum } \\
\text { Credits } \\
\quad \text { to } \\
\text { Graduate } \\
\end{array}$ & $\begin{array}{l}\text { Grade } \\
\text { Point } \\
\text { Average } \\
\text { 8th } \\
\text { Grade } \\
\end{array}$ & $\begin{array}{c}\text { 8th } \\
\text { Grade } \\
\text { Test } \\
\text { Scores }\end{array}$ & $\begin{array}{l}\text { Socio- } \\
\text { Economic } \\
\text { Status of } \\
\text { Family }\end{array}$ & $\begin{array}{l}\text { R Sq } \\
\text { RMSE }\end{array}$ \\
\hline $\begin{array}{l}\text { All } \\
\text { Vocational } \\
\text { Courses }\end{array}$ & $\begin{array}{r}2.35 \\
(2.03)\end{array}$ & $\begin{array}{c}-.323^{\star \star \star} \\
(.108)\end{array}$ & $\begin{array}{l}.050^{\star} \\
(.029)\end{array}$ & $\begin{array}{l}.054^{\star \star \star} \\
(.013)\end{array}$ & $\begin{array}{c}-.280 \star \star \star \\
(.039)\end{array}$ & $\begin{array}{c}-.335^{\star \star \star} \\
(.031)\end{array}$ & & $\begin{array}{r}.163 \\
1.874\end{array}$ \\
\hline $\begin{array}{l}\text { Introductory } \\
\text { Vocational }\end{array}$ & $\begin{array}{r}.45 \\
(.91) \\
\end{array}$ & $\begin{array}{r}.003 \\
(.045) \\
\end{array}$ & & & & & & $\begin{array}{r}.070 \\
0.872 \\
\end{array}$ \\
\hline $\begin{array}{l}\text { Occupation- } \\
\text { Vocational }\end{array}$ & $\begin{array}{r}1.32 \\
(1.69)\end{array}$ & $\begin{array}{r}-.26 \\
(.0\end{array}$ & .0 & $\begin{array}{l}.019+ \\
(.013)\end{array}$ & $\begin{array}{c}-.274^{\star \star \star} \\
(.033)\end{array}$ & & $\begin{array}{l}\star \star \star \star ~ \\
1)\end{array}$ & $\begin{array}{r}.144 \\
1.583\end{array}$ \\
\hline Computer & $\begin{array}{r}.47 \\
(.64) \\
\end{array}$ & $\begin{array}{l}-.061 \\
(.043) \\
\end{array}$ & & & & & & $\begin{array}{r}.041 \\
0.679 \\
\end{array}$ \\
\hline $\begin{array}{l}\text { Academic } \\
\text { Courses }\end{array}$ & $\begin{array}{l}15.36 \\
(3.11) \\
\end{array}$ & $\begin{array}{r}.155 \\
(.131) \\
\end{array}$ & $\begin{array}{l}.111^{\star \star \star} \\
(.039) \\
\end{array}$ & $\begin{array}{r}.019 \\
(.018) \\
\end{array}$ & $\begin{array}{c}1.111^{\star \star *} \\
(.051)\end{array}$ & $\begin{array}{l}.912^{\star \star \star \star} \\
(.041)\end{array}$ & $\begin{array}{l}3 * \star * \\
4)\end{array}$ & $\begin{array}{r}.452 \\
2.289 \\
\end{array}$ \\
\hline $\begin{array}{l}\text { Other } \\
\text { Courses }\end{array}$ & $\begin{array}{r}4.35 \\
(2.12) \\
\end{array}$ & $\begin{array}{r}.170 \\
(.142) \\
\end{array}$ & $\begin{array}{l}.151^{\star \star \star} \\
(.036)\end{array}$ & $\begin{array}{r}.018 \\
(.018) \\
\end{array}$ & $\begin{array}{c}-106^{\star \star \star} \\
(.041) \\
\end{array}$ & $\begin{array}{r}.019 \\
(.033) \\
\end{array}$ & $\begin{array}{l}.121^{\star \star \star} \\
(.039)\end{array}$ & $\begin{array}{r}.124 \\
1.995 \\
\end{array}$ \\
\hline $\begin{array}{l}\text { Vocational } \\
\text { concentrator }\end{array}$ & $\begin{array}{r}.138 \\
(.345) \\
\end{array}$ & $\begin{array}{c}-.365^{\star \star \star} \\
(.135)\end{array}$ & $\begin{array}{l}.065^{\star} \\
(.038)\end{array}$ & $\begin{array}{c}.034^{\star} \\
(.019) \\
\end{array}$ & $\begin{array}{c}.353^{\star \star \star} \\
(.054) \\
\end{array}$ & $\begin{array}{c}.295^{\star \star \star} \\
(.049) \\
\end{array}$ & $\begin{array}{c}.243^{\star \star \star} \\
(.058) \\
\end{array}$ & .093 \\
\hline \multicolumn{9}{|c|}{$\begin{array}{l}\text { Source: Authors' analysis of National Education Longitudinal Study of } 88 \text { data. } \\
\text { Note: Estimations using OLS, except the estimation of the probability of becoming vocational concentrator that it was used } \\
\text { a logit model. } \\
\text { Numbers in parenthesis below the coefficient are Huber-White standard errors that correct for clustering by school. Values } \\
\text { in brackets are F Tests of joint significance. } \\
\text { * Statistically significant at } 10 \text { percent level on a two tail test; }{ }^{* *} 5 \text { percent level; }{ }^{* *} 1 \text { percent level. }\end{array}$} \\
\hline
\end{tabular}

The most important determinant of course taking patterns was academic achievement during $8^{\text {th }}$ grade. If the Grade Point Average (GPA) ${ }^{15}$ in $8^{\text {th }}$ grade is one point higher and $8^{\text {th }}$ grade test scores are one standard deviation higher, our regression predicts the graduate will complete 2.02 additional academic courses, .07 fewer personal interest courses and .61 fewer vocational courses. The second most important determinant of course taking patterns was the socioeconomic status (SES) of one's parents. High SES students took fewer vocational courses, more academic courses and more personal interest courses.

State minimum competency exams significantly reduced the number of occupational vocational courses taken by graduates. This reduction does not come from the introductory courses (in many cases taken by those students not planning to follow a vocational career), but from the core occupational and computer courses. In fact, this would explain the large and 
negative impact on the probability of becoming vocational concentrator. The impact on academic and personal interest courses is positive and large, but not statistically significant (though closely). The effect on academic courses was expected and the positive effect on other courses could be the way how some people would free time (or effort) to focus more on the academic courses that will be tested in the MCEs exams. It is also interesting to see how, if we consider the values of the coefficients, it seems as there were some exchange between vocational and the other courses.

As expected, academic course graduation requirements had large and significant effects on the number of academic courses taken. Each one-credit increase in academic course requirements was associated with a .11 increase in the number of academic courses taken. Apparently, state minimums for academic course taking are not binding constraints for nearly 90 percent of students. Surprisingly, however, students in states with high academic course graduation requirements also took significantly more personal interest courses and more advanced vocational courses. The probability of becoming a vocational concentrator also rose slightly. A one credit increase in academic course requirements was associated with a .201 increase in credits earned in these two non-academic areas. One possible way higher academic course graduation requirements could increase personal interest course taking would be by increasing the number of periods in a school day. We checked to see whether schools scheduled more periods in the day or shorter (or longer) class periods when state government set tougher graduation requirements. Schools in MCE states had significantly more class periods per day and a significant 7 more minutes of instruction per day on average. This might be a response to the pressure of the minimum competency exams. Course graduation requirements had no such effect. Schools in states with high total course graduation requirements did not have different class schedules. Schools in states with higher academic course graduation requirements tended to schedule fewer classes per day. This makes the puzzle even harder to explain.

Finally, total course graduation requirements had no effect on the number of academic or personal interest courses taken by students but did have significant positive effects on the 
number of vocational courses. This policy also had a marginal positive effect on the probability of becoming vocational concentrator.

To sum up, tougher graduation requirements have changed course taking patterns, but the effects are small. Students in MCE states take on average one-third of a credit fewer advanced vocational courses. While this is likely to hurt some students' chances of getting a good job, the effect is small. The earnings payoff per credit is about $\$ 288$, so the net effect is only about $\$ 100$ per year.

Students who live in states that require students to take larger numbers of academic courses to graduate do not take fewer vocational courses; they take more. They also take additional personal interest courses. This suggests that the trend toward increasing course graduation requirements has caused a general increase in course taking; not a shift from nonacademic courses to academic courses. States that adopt the National Commission's recommendation require students to take a minimum of 13 academic courses. Since students now graduate with an average of 26 course credits, 18 of which are in academic subjects, only a few students will find a 13 academic course requirement to be a binding constraint. We conclude, therefore, that tougher state graduation requirements are not the sole or even a major cause of the big increase over the last 20 years in the number of academic courses taken by students. The rising payoff to college and the growing numbers of students wanting to attend college are probably the primary reasons for the increase in academic course taking from 12.9 credits in 1982 to 16.9 credits in 2000.

\section{Effects of graduation requirements on student achievement and college attendance}

This section analyzes the impact of tougher graduation requirements on college enrolment and completion and whether there is a specific impact of these policies on vocational concentrators. It must be considered that academic reform has been considered as the best way to achieve one of the main goals of the recent vocational education federal laws: increase post-secondary attendance of vocational concentrators. Making them focus more on academic courses increase their chances to go to college? More important, do these policies improve their 
chances of eventually obtaining a post-secondary degree?

As college enrolment and completion is closely related to having a solid knowledge of academic subjects, we will first analyze in this section the policies effects on test scores gains. In the second part of the section we will tackle specifically the issue of college attendance and completion.

\section{Determinants of Student Achievement}

Models were estimated predicting test score gains (increase-decrease) on four subjects (English, mathematics, science and social science) and on a composite of these four subjects during the full 4 year period from 1988 to $1992^{16}$. The composite is a simple unweighted mean of the four tests. The estimated model was:

$\mathrm{TSG}_{i j}=\alpha_{i}+\beta_{1} X_{i}+\beta_{2} \operatorname{Voc}_{\operatorname{Con}}+\beta_{3} \mathrm{MCE}_{i}+\beta_{4} A C A_{i}+\beta_{5}(\operatorname{Voc} \operatorname{Con} \times M C E)_{i}+\beta_{6}(\operatorname{Voc} \operatorname{Con} \times A C A)_{i}+\mu_{i}$

where TSG are test scores gains for individual $i$ in subject $j, X_{i}$ is a vector of control variables, VocCon is a dummy variable with value 1 if the student finished high school with a concentration in vocational education, MCE and ACA are, respectively, the variables accounting for the presence of a minimum competency exam and the number of academic courses required to graduate. Finally, we include two interaction variables between VocCon and our policy variables trying to capture specific effects for vocational concentrators ${ }^{17}$. Results are presented in table 2 
Table 2

Effects on Test Scores Gains during High School

\begin{tabular}{|c|c|c|c|c|c|}
\hline & $\begin{array}{l}\text { Test Score } \\
\text { gains in } \\
\text { English }\end{array}$ & $\begin{array}{l}\text { Test Score gains } \\
\text { in Mathematics }\end{array}$ & $\begin{array}{l}\text { Test Score } \\
\text { gains in } \\
\text { Science }\end{array}$ & \begin{tabular}{|c|} 
Test Score \\
gains in \\
Social Studies
\end{tabular} & $\begin{array}{c}\text { Gain on Academic } \\
\text { Achievement } \\
\text { Composite }\end{array}$ \\
\hline \begin{tabular}{|l|} 
Mean \\
Standard deviation
\end{tabular} & $\begin{array}{l}6.05 \\
(7.11)\end{array}$ & $\begin{array}{c}8.69 \\
(5.52)\end{array}$ & $\begin{array}{c}7.42 \\
(7.42)\end{array}$ & $\begin{array}{c}9.51 \\
(7.12)\end{array}$ & $\begin{array}{c}7.90 \\
(4.77)\end{array}$ \\
\hline $\begin{array}{l}\text { Vocational } \\
\text { concentrator }\end{array}$ & $\begin{array}{l}.195 \\
(.392)\end{array}$ & $\begin{array}{l}-.040 \\
(.296)\end{array}$ & $\begin{array}{c}.441 \\
(.433)\end{array}$ & $\begin{array}{l}.008 \\
(.438)\end{array}$ & $\begin{array}{l}.158 \\
(.265)\end{array}$ \\
\hline $\begin{array}{l}\text { State Minimum } \\
\text { Competency Exam }\end{array}$ & $\begin{array}{l}.170 \\
(.307)\end{array}$ & $\begin{array}{l}.503^{\star} \\
(.267)\end{array}$ & $\begin{array}{l}.445 \\
(.348)\end{array}$ & $\begin{array}{l}.489 \\
(.391)\end{array}$ & $\begin{array}{l}.397^{\star} \\
(.233)\end{array}$ \\
\hline $\begin{array}{l}\text { State MCE*Voc } \\
\text { concentrator }\end{array}$ & $\begin{array}{l}-.944^{\star *} \\
(.488)\end{array}$ & $\begin{array}{l}-.293 \\
(.356)\end{array}$ & $\begin{array}{l}-.990^{\star} \\
(.531)\end{array}$ & $\begin{array}{l}.192 \\
(.572)\end{array}$ & $\begin{array}{l}-.606^{*} \\
(.333)\end{array}$ \\
\hline $\begin{array}{l}\text { MCE on vocational } \\
\text { concentrators }\end{array}$ & $\begin{array}{l}-.774+ \\
{[2.34]}\end{array}$ & $\begin{array}{l}.210 \\
{[0.27]}\end{array}$ & $\begin{array}{l}-.545 \\
{[0.83]}\end{array}$ & $\begin{array}{c}.681 \\
{[1.16]}\end{array}$ & $\begin{array}{l}-.209 \\
{[0.30]}\end{array}$ \\
\hline \begin{tabular}{|l|} 
Academic Courses \\
Required to \\
Graduate
\end{tabular} & $\begin{array}{l}-.038 \\
(.090)\end{array}$ & $\begin{array}{l}-.060 \\
(.069)\end{array}$ & $\begin{array}{l}.014 \\
(.095)\end{array}$ & $\begin{array}{l}.243^{\star \star} \\
(.110)\end{array}$ & $\begin{array}{l}.032 \\
(.064)\end{array}$ \\
\hline \begin{tabular}{|l|} 
Academic \\
Courses*Voc \\
concentrator \\
\end{tabular} & $\begin{array}{l}.143 \\
(.133)\end{array}$ & $\begin{array}{l}.048 \\
(.099)\end{array}$ & $\begin{array}{l}.003 \\
(.151)\end{array}$ & $\begin{array}{l}.014 \\
(.157)\end{array}$ & $\begin{array}{l}0.067 \\
(.094)\end{array}$ \\
\hline \begin{tabular}{|l|} 
Academic on \\
vocational \\
concentrators
\end{tabular} & $\begin{array}{l}.105 \\
{[0.52]}\end{array}$ & $\begin{array}{l}-.012 \\
{[0.01]}\end{array}$ & $\begin{array}{c}.017 \\
{[0.01]}\end{array}$ & $\begin{array}{l}.257+ \\
{[2.15]}\end{array}$ & $\begin{array}{c}.099 \\
{[0.90]}\end{array}$ \\
\hline $\begin{array}{l}\text { State Minimum } \\
\text { Credits to } \\
\text { Graduate }\end{array}$ & $\begin{array}{l}.004 \\
(.040)\end{array}$ & $\begin{array}{c}-.069 * \star \\
(.032)\end{array}$ & $\begin{array}{l}-.048 \\
(.040)\end{array}$ & $\begin{array}{l}.008 \\
(.040)\end{array}$ & $\begin{array}{l}-.024 \\
(.027)\end{array}$ \\
\hline \begin{tabular}{|l|} 
Introductory \\
Vocational
\end{tabular} & $\begin{array}{l}-.042 \\
(.095)\end{array}$ & $\begin{array}{c}-.293^{\star \star \star} \\
(.075)\end{array}$ & $\begin{array}{l}-.172^{*} \\
(.095)\end{array}$ & $\begin{array}{l}-.062 \\
(.091)\end{array}$ & $\begin{array}{l}-.145^{\star \star \star} \\
(.056)\end{array}$ \\
\hline \begin{tabular}{|l|} 
Occupation \\
Vocational \\
\end{tabular} & $\begin{array}{l}.057 \\
(.077) \\
\end{array}$ & $\begin{array}{l}-.140 * * \\
(.063) \\
\end{array}$ & $\begin{array}{l}-.078 \\
(.088) \\
\end{array}$ & $\begin{array}{l}-.094 \\
(.090) \\
\end{array}$ & $\begin{array}{l}-.053 \\
(.054) \\
\end{array}$ \\
\hline Computer & $\begin{array}{l}.413^{\star \star \star} \\
(.128)\end{array}$ & $\begin{array}{l}.430 \star \star \star \\
(.096)\end{array}$ & $\begin{array}{l}.135 \\
(.131) \\
\end{array}$ & $\begin{array}{l}.092 \\
(.133) \\
\end{array}$ & $\begin{array}{l}.243^{\star \star \star} \\
(.082)\end{array}$ \\
\hline Academic Courses & $\begin{array}{l}.390^{\star \star \star} \\
(.042)\end{array}$ & $\begin{array}{l}.469^{\star \star \star} \\
(.034)\end{array}$ & $\begin{array}{l}.385^{\star \star \star} \\
(.046)\end{array}$ & $\begin{array}{l}.295^{\star \star \star} \\
(.045)\end{array}$ & $\begin{array}{l}.373^{\star \star \star} \\
(.029)\end{array}$ \\
\hline Other Courses & $\begin{array}{l}.045 \\
(.044) \\
\end{array}$ & $\begin{array}{l}-.004 \\
(.034) \\
\end{array}$ & $\begin{array}{l}.052 \\
(.046) \\
\end{array}$ & $\begin{array}{l}.010 \\
(.047) \\
\end{array}$ & $\begin{array}{l}.021 \\
(.029) \\
\end{array}$ \\
\hline $\begin{array}{l}\text { Grade Point } \\
\text { Average in } 8^{\text {th }} \\
\text { Grade }\end{array}$ & $\begin{array}{l}-.005 \\
(.155)\end{array}$ & $\begin{array}{l}.601^{\star \star \star} \\
(.124)\end{array}$ & $\begin{array}{l}.331^{\star \star} \\
(.162)\end{array}$ & $\begin{array}{l}.154 \\
(.162)\end{array}$ & $\begin{array}{l}.170^{\star} \\
(.102)\end{array}$ \\
\hline $\begin{array}{l}\text { Socio-Economic } \\
\text { Status }\end{array}$ & $\begin{array}{c}.048 \\
(.145)\end{array}$ & $\begin{array}{l}.186 \\
(.115) \\
\end{array}$ & $\begin{array}{l}.165 \\
(.162) \\
\end{array}$ & $\begin{array}{l}.143 \\
(.150)\end{array}$ & $\begin{array}{l}.069 \\
(.097)\end{array}$ \\
\hline $\begin{array}{l}\text { Number of } \\
\text { observations }\end{array}$ & 7977 & 7978 & 7924 & 7868 & 8004 \\
\hline $\begin{array}{l}R^{2} \\
\text { Root MSE }\end{array}$ & $\begin{array}{r}.062 \\
6.908 \\
\end{array}$ & $\begin{array}{r}.136 \\
5.130 \\
\end{array}$ & $\begin{array}{l}.088 \\
7.222 \\
\end{array}$ & $\begin{array}{r}.050 \\
6.992 \\
\end{array}$ & $\begin{array}{r}.123 \\
4.502 \\
\end{array}$ \\
\hline
\end{tabular}

Source: Authors' analysis of National Education Longitudinal Study of 88 data.

Note: Estimations using OLS. Numbers in parenthesis below the coefficient are Huber-White standard errors that correct for clustering by school.

Values in brackets are $\mathrm{F}$ Tests of joint significance.

* Statistically significant at 10 percent level on a two tail test; ** 5 percent level; *** 1 percent level. 
Course taking patterns are clearly very important predictors of learning during high school. Holding $8^{\text {th }}$ grade GPA, other $8^{\text {th }}$ grade test scores and other high school courses constant, academic courses were associated with substantial gains in math, science, social studies and English. Each extra academic course taken was associated with a .189 grade level equivalent (GLE) gain in the overall composite ${ }^{18}$. This is a large effect. It implies that students who cram five extra academic courses into a four-year high school program are predicted to learn 95 percent of a grade level equivalent more than other students. In other words they end up with five years worth of academic learning, not four like everybody else. In the US, academic courses typically become more difficult as one takes more of them, so the number of courses and their rigor are positively correlated. Nevertheless, these large and significant coefficients suggest that time devoted to academic courses pays off in larger test score gains. Personal interest courses_art, music, health, physical education, etc—by contrast, had no effect on academic learning. Vocational courses had different effects on the test score composite depending on the specific types of courses considered. Introductory vocational courses taken during high school were associated with significantly reduced learning, concentrated in math and science. Occupational vocational courses are associated with lower gains on the mathematics achievement tests but not for other subjects. The large and positive effect of the computer courses on the test score gains in mathematics, in English and in the test score composite are quite interesting. They suggest that there was a great deal of wisdom in the National Commission's recommendation that all students take at least one computer course ${ }^{19}$

Effects of Course Graduation Requirements: The impact of the policies on students' learning is produced by two effects: firstly, a direct effect, responding to the changing students' behaviour when faced with these policies; secondly, an indirect effect operating through the changes in course taking patterns provoked by the policies. Thus, in order to obtain the total effect, we need to calculate this indirect effect and add it to the direct one. The indirect effect is calculated as: 


$$
\sum_{i=1}^{5}((\text { effect of policy } y \text { on subject } i) *(\text { effect of subject } i \text { on outcome } k))
$$

where $i$ represents the five types of courses considered, $y$ represents the three policies analyzed and $k$ the different outcomes that are predicted.

The first finding is that increasing the total number of credits required to graduate has absolutely no effect on learning. Academic course taking does not increase and the calculated total effect is both tiny and negative.

The results are quite different for academic course requirements. A one-unit increase in academic course graduation requirements produces an indirect effect of $0.047^{20}$, that added to the direct effect 0.032 (see table 2, column 6, row 7) gives us a total effect of 0.079 or, what's the same, 0.040 grade level equivalents $(G L E)^{21}$. This means that a three-unit increase in academic course requirements is predicted to raise average achievement by 12 percent of a grade level equivalent. This effect may seem small but that is because most students are not affected by it-they were already taking plenty of academic courses. When however, the constraint is binding, the policy does result in the students who were forced to take extra academic courses learning considerably more. Vocational concentrators are more likely to be affected by the requirement and as a result, the requirement should have larger effect on them than on nonconcentrators. The interaction variable presented in row 8 of Table 2 will allow us to tackle this issue, as it measures the differential impact of academic courses requirement on the test score gains of vocational concentrators. Row 9 presents our estimate of the direct effect of MCEs on vocational concentrators (the sum of the coefficients in row 7 and 8). The interaction effect is positive in almost all of the test variables, but with low level of significance. Nevertheless, when the direct effect is added to the indirect effect, a three unit increase in required academic courses produces .23 GLEs extra learning. The impact, thus, is quite important, doubling the impact produced on non-vocational concentrators. 
Effects of Minimum Competency Exams: State MCEs generate for non-vocational concentrators quite large and positive effects on test score gains in all the subjects, being significant for the test composite and mathematics. Adding the indirect effect, we obtain a total effect of about 0.24 GLEs of extra learning in the test composite over the four year interval ${ }^{22}$.

Do these comments hold for vocational concentrators? The answer is clearly not. All except one of the coefficients on the interaction variable (row 5) are negative, and three of them are statistically significant. Adding direct and indirect effects for the test composite, we obtain a reduction of .08 GLEs in learning.

Why does an MCE seem to result in greater learning for non-vocational students but not for vocational students? Could it be that most students try harder in their academic classes when they must pass a MCE to graduate, but vocational concentrators do not? We checked this hypothesis directly by including interaction variables in a model predicting the answers to the following question: "In each of your current classes [math, English, science and social studies], how often do you try as hard as you can." Our results show a positive and significant effect of MCEs on the indicator of self-perceived effort, but we also obtain a negative coefficient for the interaction variable. Then, when faced with a MCE, most students work harder in their academic courses and learn more. There is, however, no evidence that vocational concentrators responded in a similar manner.

\section{Determinants of College Enrolment Rates and Completion}

Tougher high school graduation requirements are meant to induce students to study harder and take additional academic courses, so one would expect them to increase the proportion of high school graduates who attend and complete college. We tested this hypothesis in logistic models using the same econometric specification as in the previous section. Models were run for short term results (enrolling in any type of postsecondary education right after graduation from high school and being enrolled four semesters later) and for medium term results (having obtained an associate degree or higher by the year 2000 and having obtained bachelor degree or higher by the year 2000). 
Table 3

College Attendance and Completion

\begin{tabular}{|c|c|c|c|c|}
\hline & $\begin{array}{l}\text { Enrolled in } \\
\text { Fall } 1992\end{array}$ & $\begin{array}{l}\text { Enrolled in } \\
\text { Spring } 1994\end{array}$ & $\begin{array}{c}\text { Obtained an } \\
\text { associate or } \\
\text { higher }\end{array}$ & $\begin{array}{c}\text { Obtained a } \\
\text { bachelor or } \\
\text { higher }\end{array}$ \\
\hline $\begin{array}{l}\text { Mean } \\
\text { Standard deviation }\end{array}$ & $\begin{array}{r}.622 \\
(.485) \\
\end{array}$ & $\begin{array}{l}.577 \\
(.494)\end{array}$ & $\begin{array}{c}.407 \\
(.491)\end{array}$ & $\begin{array}{l}.334 \\
(.472) \\
\end{array}$ \\
\hline Vocational concentrator & $\begin{array}{l}-.189 \\
(.150)\end{array}$ & $\begin{array}{l}-.097 \\
(.147)\end{array}$ & $\begin{array}{l}-.132 \\
(.166)\end{array}$ & $\begin{array}{l}-.166 \\
(.193)\end{array}$ \\
\hline $\begin{array}{l}\text { State Minimum Competency } \\
\text { Exam }\end{array}$ & $\begin{array}{l}-.045 \\
(.107) \\
\end{array}$ & $\begin{array}{l}-.048 \\
(.094)\end{array}$ & $\begin{array}{l}-.077 \\
(.110)\end{array}$ & $\begin{array}{l}-.275^{\star \star} \\
(.129)\end{array}$ \\
\hline State MCE*Voc concentrator & $\begin{array}{l}.292^{*} \\
(.175)\end{array}$ & $\begin{array}{l}.314^{*} \\
(.166)\end{array}$ & $\begin{array}{l}.147 \\
(.201)\end{array}$ & $\begin{array}{l}.303 \\
(.250)\end{array}$ \\
\hline $\begin{array}{l}\text { MCE on vocational } \\
\text { concentrators }\end{array}$ & $\begin{array}{l}.246+ \\
{[1.79]}\end{array}$ & $\begin{array}{l}.266+ \\
{[2.44]}\end{array}$ & $\begin{array}{c}.070 \\
{[0.11]}\end{array}$ & $\begin{array}{c}.028 \\
{[0.01]}\end{array}$ \\
\hline $\begin{array}{l}\text { Academic Courses Required to } \\
\text { Graduate }\end{array}$ & $\begin{array}{l}-.041 \\
(.030)\end{array}$ & $\begin{array}{l}-.041 \\
(.028)\end{array}$ & $\begin{array}{l}-.040 \\
(.030)\end{array}$ & $\begin{array}{l}-.072^{\star *} \\
(.037)\end{array}$ \\
\hline $\begin{array}{l}\text { Academic Courses* }{ }^{*} \text { oc } \\
\text { concentrator }\end{array}$ & $\begin{array}{l}-.091^{*} \\
(.052)\end{array}$ & $\begin{array}{l}-.106^{\star *} \\
(.048)\end{array}$ & $\begin{array}{l}-.082 \\
(.057)\end{array}$ & $\begin{array}{c}.016 \\
(.068)\end{array}$ \\
\hline $\begin{array}{l}\text { Academic on vocational } \\
\text { concentrators }\end{array}$ & $\begin{array}{c}-.131^{\star \star \star} \\
{[6.07]}\end{array}$ & $\begin{array}{l}-.147^{\star \star \star} \\
{[9.02]}\end{array}$ & $\begin{array}{l}-.122^{\star *} \\
{[4.45]}\end{array}$ & $\begin{array}{l}-.056 \\
{[0.66]}\end{array}$ \\
\hline $\begin{array}{l}\text { State Minimum Credits to } \\
\text { Graduate }\end{array}$ & $\begin{array}{c}-.041^{* * *} \\
(.014)\end{array}$ & $\begin{array}{c}-.038^{* \star *} \\
(.013)\end{array}$ & $\begin{array}{l}-.024^{*} \\
(.014)\end{array}$ & $\begin{array}{l}-.011 \\
(.017)\end{array}$ \\
\hline Introductory Vocational & $\begin{array}{l}.058^{*} \\
(.032)\end{array}$ & $\begin{array}{l}-.029 \\
(.034)\end{array}$ & $\begin{array}{l}-.045 \\
(.044)\end{array}$ & $\begin{array}{l}-.081 \\
(.052)\end{array}$ \\
\hline Occupation- Vocational & $\begin{array}{l}.065^{\star *} \\
(.029)\end{array}$ & $\begin{array}{l}.016 \\
(.030)\end{array}$ & $\begin{array}{c}.031 \\
(.032)\end{array}$ & $\begin{array}{l}-.022 \\
(.038)\end{array}$ \\
\hline Computer & $\begin{array}{l}.173^{* * *} \\
(.048)\end{array}$ & $\begin{array}{l}.083^{*} \\
(.048)\end{array}$ & $\begin{array}{l}.120^{* \star *} \\
(.046)\end{array}$ & $\begin{array}{l}.122^{\star \star \star} \\
(.051)\end{array}$ \\
\hline Academic Courses & $\begin{array}{l}.298^{\star \star \star} \\
(.016)\end{array}$ & $\begin{array}{l}.244^{\star \star *} \\
(.016)\end{array}$ & $\begin{array}{l}.242^{\star \star \star} \\
(.016)\end{array}$ & $\begin{array}{l}.307^{\star \star \star} \\
(.019)\end{array}$ \\
\hline Other Courses & $\begin{array}{l}.088^{\star * \star} \\
(.016)\end{array}$ & $\begin{array}{l}.030^{* *} \\
(.016)\end{array}$ & $\begin{array}{l}.038^{* *} \\
(.017)\end{array}$ & $\begin{array}{l}.034^{*} \\
(.019)\end{array}$ \\
\hline $\begin{array}{l}\text { Grade Point Average in } 8^{\text {th }} \\
\text { Grade }\end{array}$ & $\begin{array}{l}.412^{\star \star \star} \\
(.054)\end{array}$ & $\begin{array}{l}.380^{* \star *} \\
(.052)\end{array}$ & $\begin{array}{l}.606^{\star \star *} \\
(.064)\end{array}$ & $\begin{array}{l}.834^{\star \star \star} \\
(.052)\end{array}$ \\
\hline 8th Grade Test Scores & $\begin{array}{l}.284^{\star \star *} \\
(.047)\end{array}$ & $\begin{array}{l}.267^{\star \star \star} \\
(.046)\end{array}$ & $\begin{array}{l}.188^{\star \star *} \\
(.050)\end{array}$ & $\begin{array}{l}.234^{\star \star *} \\
(.046)\end{array}$ \\
\hline Socio-Economic Status & $\begin{array}{l}.563^{\star \star \star} \\
(.054)\end{array}$ & $\begin{array}{l}.621^{* \star *} \\
(.056)\end{array}$ & $\begin{array}{l}.536^{* \star \star} \\
(.054)\end{array}$ & $\begin{array}{l}.686^{\star \star *} \\
(.056)\end{array}$ \\
\hline Number of observations & 7378 & 7385 & 6364 & 6364 \\
\hline Pseudo $\mathrm{R}^{2}$ & .254 & .246 & .263 & .355 \\
\hline
\end{tabular}

Source: Authors' analysis of National Education Longitudinal Study of 88 data.

Note: Estimations using a logit model. Numbers in parenthesis below the coefficient are Huber-White standard errors that correct for clustering by school. Values in brackets are F Tests of joint significance.

* Statistically significant at 10 percent level on a two tail test; ** 5 percent level; *** 1 percent level. 
We first analyse the short term results (columns 1 and 2 of the table 3 ). The number of academic course credits earned in high school was a very strong predictor of college attendance. One additional academic course was associated with college attendance rates that were 6 to 7 percentage points higher. Occupational vocational courses and personal interest courses had positive effects on college attendance rates but the size of the effect was smaller than that for academic courses. Computer courses, by contrast, had significant effects on college attendance. One additional course of this type was associated with college attendance rates that were 4 percentage points higher in the fall of 1992 and 2 points higher in the spring of 1994 . Thus substituting an occupational vocational course for personal interest courses has no effect on college attendance rates. Substituting a vocational course for an academic course, however, lowers college attendance rates by about 5 percentage points per course. Taking a heavy schedule of vocational courses and becoming a vocational concentrator is also associated with a 3 to 6 percentage point reduction in college attendance rates ${ }^{23}$.

Effects of Minimum Competency Exams on College Enrolment: We found that state MCEs had no significant effects on college attendance rates of students who did not do a vocational concentration (point estimates are negative though not significantly different from zero). MCEs did, however, have strong positive effects on college attendance rates of vocational concentrators. Holding course-taking patterns constant, attending a high school with MCE graduation requirements raised college attendance rates of vocational concentrators by 9 to 11 percent. Since MCE's induce students to take more academic courses, the indirect effects of MCEs on college attendance reinforce the direct effects. The lack of positive effects of MCEs on test score gains of vocational concentrators suggests that MCEs increase college attendance by raising college aspirations.

Effects of Course Graduation Requirements on College Enrolment: The effects of higher state minimum course graduation requirements on college attendance are significantly negative. A two credit increase in the total number of courses required to graduate reduced predicted 
college enrolment rates by 3 percent in the fall 1992 and Spring 1994, although since this policy has also indirect effects, the total effect is a smaller reduction of about 1.5 percent.

Now let us examine the effect of increases in academic course requirements while holding total course requirements fixed. The direct effects are again negative for non-vocational concentrators, although the coefficients are not significant. However, the increase in the number of academic courses brought about by the graduation requirement has the opposite effect, so we must sum direct and indirect effects to assess total effects of the policy. Our regressions imply that the indirect effects of increases in state academic course requirements offset the negative direct effects of the policy, so the total effects of the policy on college attendance rates are essentially zero. The situation is different for vocational concentrators. The direct effect is significantly negative and, even though the indirect effect has a positive impact on the probability of attending college, the final result is a reduction of this probability of almost 3 percent in Fall 1992 and 4.7 percent in Spring 1994.

Let's know turn our attention to the medium term results (columns 3 and 4 of table 3 ). Once again we found that academic courses are important, as they have a positive and strong association with getting an associate degree or higher. Among vocational education courses, only computer courses have a rather sizable positive relationship. Personal interest courses have a small but positive and statistically significant effect.

Effects of Minimum Competency Exams on College Completion: We found that an MCE reduces the probability that students who are not vocational concentrators will obtain a bachelor degree or higher. When direct and indirect effects are added, an MCE is predicted to lower the probability of obtaining a bachelor degree by about 14 percent but awards of lower level degrees remain pretty much the same.

Vocational concentrators, by contrast, are not predicted to be less likely to get a postsecondary credential when they live in a MCE state, although there isn't a significant positive effect either. When direct and indirect effects are summed, the predicted probability of getting an associates degree or a bachelors degree is 5 percent higher in MCE states. MCEs encourage 
vocational concentrators to enter postsecondary education and about half of them get either a bachelors degree, an associates degree or professional license.

Effects of Course Graduation Requirements on College Completion: When direct and indirect effects are combined, we calculate that higher academic requirements have small negative effects on the number of non-vocational students getting postsecondary credentials. States that require two additional academic courses to graduate are predicted to have about 4 percent fewer non-vocational students getting a bachelors degree. The probability of getting a license or an associates degree or better is unaffected. This implies that students living in states with high course graduation requirements are equally likely to get a postsecondary credential but the credential is more likely to be an associates degree.

High academic course requirements have even bigger negative effects on vocational concentrators. They are about 9 percent less likely to get an associates or a higher degree when they live in a state that requires two extra academic courses to graduate.

This implies that even though graduates who take extra academic courses in high school are much more likely to go to college, requiring students to take more academic courses by raising graduation requirements does not increase college attendance rates for most students and rates of completing college appear to decline slightly. In addition, when academic course requirements are held constant, the states with high total number of courses required to graduate have significantly lower college attendance rates and lower probabilities of graduates getting an Associates or higher degree.

\section{Effects of graduation requirements on post high school labor market outcomes}

As we briefly commented in the introduction, MCEs are hypothesized to improve job opportunities in two ways. First, there is the learning effect acting by improving student achievement and raising worker productivity (Bishop, 1992). Even when this does not immediately raise workers' earnings, the effect of academic achievement on wages grows with time and eventually becomes very large (Farber and Gibbons, 1996; Altonji and Pierret, 2000). Note that this learning effect also applies to the second educational policy analyzed, increasing number of 
academic courses required to graduate. It is important to understand that there are two sources of potential improvement in worker productivity. The first one is a direct effect of academic knowledge on the skills needed to perform in the current labor market. The second one is an indirect effect that works through the ability to learn new skills something that basic academic skills (not "narrow" vocational training) is supposed to enhance.

The second effect is the signaling effect. MCEs are hypothesized to improve job opportunities by sending a signal to employers that "ALL the graduates of this high school meet or exceed your hiring standards." The fact that they have passed the MCE is the proof. In most communities, competencies developed in the local high school are poorly signaled to employers. The lack of signals of achievement in high school tends to make employers with the best jobs reluctant to risk hiring recent high school graduates. Indeed they often carry in their head very negative stereotypes regarding recent high school graduates. They prefer, instead, to hire workers with many years of work experience because the applicant's work record serves as a signal of competence and reliability that helps them identify the most qualified.

Establishing a minimum competency exam, therefore, is one way a school district or state education system can try to overcome this signaling problem and help its graduates get good jobs. With the MCE requirement, the school's diploma now signals more than just seat time; it signals meeting or exceeding certain minimum standards in reading, writing, mathematics, science and social studies as well. Efforts to convince employers that students now graduating from high school have the academic skills they want appear to be succeeding. Public Agenda's 2001 survey of a representative sample of employers who make hiring decisions for jobs often filled by recent high school graduates found that "Employers still voice considerable doubts about student's basic skills, but almost two-thirds (64 percent) acknowledge that students don't graduate from local schools unless they have learned what was expected of them, up from 51 percent in 1999 (Johnson et al., 2001: p. S3)."

Because of pooling, all high school graduates should benefit from a MCE regime. The positive effects of MCEs on the reputation of a recent graduate may be particularly large for 
vocational concentrators. When there is no MCE graduation requirement, local employers may suspect that vocational concentrators have poor basic skills. The MCE requirement takes that stigma away and allows employers to focus instead on the occupation specific skills they can anticipate getting when they hire a recent graduate of a high school vocational program.

Previous studies have found that MCEs have a positive impact on labor market outcomes. Analyzing High School and Beyond data (high school graduates in 1980) and controlling for college attendance and a host of other variables, Bishop, Moriarty and Mane (2000) found that females graduating from high schools with a minimum competency exam graduation requirement [student report] earned more than women graduating from schools without an MCE. Concern about the accuracy of student reports of the existence of a MCE at their high school led Bishop and Mane (2001a) to reanalyze HSB data using principal reports of the existence of a MCE graduation requirement. They found even larger effects. Principal reports of a MCE graduation requirement had positive effects (significant in some but not all years) on wage rates of male and female graduates and on the earnings of graduates four and five years after graduation. The wage rate effects of MCE's appeared to be larger for students in the bottom three quarters of the test score distribution. Finally, using NELS-88 data (high school graduates in 1992) Bishop and Mane (2001b) found that students who attended school in states with MCEs earned about 7 percent more per month than students in states without MCEs.

In this paper extend this literature by (a) looking at medium-term labor market outcomes as well as short run outcomes, (b) studying the effects of course graduation requirements as well and (c) comparing policy effects on vocational concentrators to effects on students who did not concentrate on a vocational field. We hypothesize that these policies have larger effects on vocational concentrators than on non-concentrators. Students who choose to pursue a vocational concentration tend to have lower grades and test scored in $8^{\text {th }}$ grade than students who choose a more academic focus to their high school studies. They are therefore at higher risk of failing the minimum competency exam or being forced to take additional academic courses by a high state minimum graduation requirement. 
Short-term effects of MCEs and Academic Requirements: Models were estimated predicting three indicators of early labor market outcomes: earnings in calendar year 1993, the hourly wage rate of the last job and the total number of months worked during the 21 month period following high school graduation. With two exceptions the models predicting these labor market outcomes were the same as those used to predict college attendance ${ }^{24}$. Results are presented in Table 4.

Table 4

\section{Labor Market Effects}

\begin{tabular}{|c|c|c|c|c|c|c|}
\hline & \multicolumn{3}{|c|}{ Short term results } & \multicolumn{3}{|c|}{ Medium term results } \\
\hline & $\begin{array}{c}\text { Employment } \\
\text { (months) }\end{array}$ & $\begin{array}{c}\text { Wages } \\
\text { (log hourly } \\
\text { wage) }\end{array}$ & $\begin{array}{c}\text { Earnings } \\
\text { (yearly) }\end{array}$ & $\begin{array}{c}\text { Employment } \\
\text { (hours week) }\end{array}$ & $\begin{array}{l}\text { Wages } \\
\text { (log hr } \\
\text { wage) }\end{array}$ & $\begin{array}{c}\text { Earnings } \\
\text { (yearly) }\end{array}$ \\
\hline $\begin{array}{l}\text { Mean } \\
\text { Standard deviation }\end{array}$ & $\begin{array}{l}14.15 \\
(7.45)\end{array}$ & $\begin{array}{l}1.292 \\
(.557)\end{array}$ & $\begin{array}{c}5427 \\
(5394)\end{array}$ & $\begin{array}{c}36.75 \\
(15.33)\end{array}$ & $\begin{array}{c}2.53 \\
(.436)\end{array}$ & $\begin{array}{c}26535 \\
(18953)\end{array}$ \\
\hline Vocational concentrator & $\begin{array}{l}-.237 \\
(.414)\end{array}$ & $\begin{array}{l}-.043 \\
(.034)\end{array}$ & $\begin{array}{l}-311 \\
(343)\end{array}$ & $\begin{array}{l}.323 \\
(.745)\end{array}$ & $\begin{array}{l}.026 \\
(.026)\end{array}$ & $\begin{array}{l}1087 \\
(327)\end{array}$ \\
\hline State Minimum Competency Exam & $\begin{array}{l}-.029 \\
(.336)\end{array}$ & $\begin{array}{l}.010 \\
(.020)\end{array}$ & $\begin{array}{l}456^{\star \star} \\
(195)\end{array}$ & $\begin{array}{l}.784 \\
(.572)\end{array}$ & $\begin{array}{l}.039^{\star \star} \\
(.018)\end{array}$ & $\begin{array}{c}2277^{\star \star \star} \\
(748)\end{array}$ \\
\hline State MCE*Voc concentrator & $\begin{array}{l}.792^{\star} \\
(.484)\end{array}$ & $\begin{array}{l}.051 \\
(.040)\end{array}$ & $\begin{array}{c}157 \\
(442)\end{array}$ & $\begin{array}{l}-2.389^{\star \star \star} \\
(.929)\end{array}$ & $\begin{array}{l}.040 \\
(.033)\end{array}$ & $\begin{array}{c}-842 \\
(1446)\end{array}$ \\
\hline MCE on vocational concentrators & $\begin{array}{l}.763+ \\
{[2.20]}\end{array}$ & $\begin{array}{l}.061+ \\
{[2.32]}\end{array}$ & $\begin{array}{c}613 \\
{[1.93]}\end{array}$ & $\begin{array}{c}-1.605^{\star} \\
{[2.71]}\end{array}$ & $\begin{array}{l}.079 * \star \star \\
{[5.70]}\end{array}$ & $\begin{array}{l}1435 \\
{[1.09]}\end{array}$ \\
\hline $\begin{array}{l}\text { Academic Courses Required to } \\
\text { Graduate }\end{array}$ & $\begin{array}{l}.030 \\
(.088)\end{array}$ & $\begin{array}{l}.015^{\star *} \\
(.006)\end{array}$ & $\begin{array}{c}68 \\
(59)\end{array}$ & $\begin{array}{l}.124 \\
(.147)\end{array}$ & $\begin{array}{l}.009^{*} \\
(.005)\end{array}$ & $\begin{array}{l}423^{\star *} \\
(205)\end{array}$ \\
\hline Academic Courses*Voc concentrator & $\begin{array}{l}.204 \\
(.141)\end{array}$ & $\begin{array}{l}.003 \\
(.010)\end{array}$ & $\begin{array}{c}3 \\
(125)\end{array}$ & $\begin{array}{c}.329 \\
(.235)\end{array}$ & $\begin{array}{l}-.014^{\star} \\
(.007)\end{array}$ & $\begin{array}{l}-243 \\
(340)\end{array}$ \\
\hline Academic on vocational concentrators & $\begin{array}{l}.234+ \\
{[2.56]}\end{array}$ & $\begin{array}{c}.018 \\
{[1.19]}\end{array}$ & $\begin{array}{c}71 \\
{[0.58]}\end{array}$ & $\begin{array}{l}.453^{\star \star} \\
{[3.44]}\end{array}$ & $\begin{array}{l}-.005 \\
{[0.32]}\end{array}$ & $\begin{array}{c}180 \\
{[0.25]}\end{array}$ \\
\hline State Minimum Credits to Graduate & $\begin{array}{l}-.004 \\
(.039)\end{array}$ & $\begin{array}{l}-.008^{\star \star \star} \\
(.002)\end{array}$ & $\begin{array}{l}-22 \\
(27)\end{array}$ & $\begin{array}{l}-.013 \\
(.071)\end{array}$ & $\begin{array}{c}-.006^{\star \star \star} \\
(.002)\end{array}$ & $\begin{array}{c}-215^{\star \star} \\
(97)\end{array}$ \\
\hline Introductory Vocational & $\begin{array}{l}.086 \\
(.096)\end{array}$ & $\begin{array}{l}.015^{\star \star} \\
(.007)\end{array}$ & $\begin{array}{l}100 \\
(87)\end{array}$ & $\begin{array}{c}.286 \\
(.203)\end{array}$ & $\begin{array}{l}-.003 \\
(.006)\end{array}$ & $\begin{array}{c}-6 \\
(245) \\
\end{array}$ \\
\hline Occupation-Vocational & $\begin{array}{l}.106 \\
(.080)\end{array}$ & $\begin{array}{l}.026^{\star \star \star} \\
(.006)\end{array}$ & $\begin{array}{c}288^{\star \star \star} \\
(63)\end{array}$ & $\begin{array}{l}.428^{\star \star \star} \\
(.155)\end{array}$ & $\begin{array}{l}.001 \\
(.005)\end{array}$ & $\begin{array}{c}256 \\
(223)\end{array}$ \\
\hline Computer & $\begin{array}{l}-.124 \\
(.129) \\
\end{array}$ & $\begin{array}{l}-.001 \\
(.009) \\
\end{array}$ & $\begin{array}{c}17 \\
(90)\end{array}$ & $\begin{array}{c}.268 \\
(.239) \\
\end{array}$ & $\begin{array}{l}.010 \\
(.008)\end{array}$ & $\begin{array}{l}744^{\star *} \\
(366)\end{array}$ \\
\hline Academic Courses & $\begin{array}{l}-.095^{\star \star} \\
(.042)\end{array}$ & $\begin{array}{l}-.005^{\star} \\
(.003)\end{array}$ & $\begin{array}{l}-52^{*} \\
(31)\end{array}$ & $\begin{array}{l}.096 \\
(.077)\end{array}$ & $\begin{array}{l}-.003 \\
(.002)\end{array}$ & $\begin{array}{l}-126 \\
(100)\end{array}$ \\
\hline Other Courses & $\begin{array}{l}-.022 \\
(.044)\end{array}$ & $\begin{array}{l}.002 \\
(.003)\end{array}$ & $\begin{array}{l}-40 \\
(33)\end{array}$ & $\begin{array}{l}-.122 \\
(.087)\end{array}$ & $\begin{array}{l}-.004 \\
(.003)\end{array}$ & $\begin{array}{c}-289^{\star \star \star} \\
(108)\end{array}$ \\
\hline Grade Point Average in $8^{\text {th }}$ Grade & $\begin{array}{l}.036 \\
(.161)\end{array}$ & $\begin{array}{c}.008 \\
(.012)\end{array}$ & $\begin{array}{c}-94 \\
(125)\end{array}$ & $\begin{array}{l}.256 \\
(.310)\end{array}$ & $\begin{array}{l}.034^{\star \star \star} \\
(.011)\end{array}$ & $\begin{array}{c}1063^{\star \star \star} \\
(401)\end{array}$ \\
\hline $8^{\text {th }}$ Grade Test Scores & $\begin{array}{l}.139 \\
(.136)\end{array}$ & $\begin{array}{l}.020^{\star *} \\
(.009)\end{array}$ & $\begin{array}{c}193^{\star *} \\
(98)\end{array}$ & $\begin{array}{l}-.408 \\
(.266)\end{array}$ & $\begin{array}{l}.005 \\
(.008)\end{array}$ & $\begin{array}{c}75 \\
(337)\end{array}$ \\
\hline Socio-Economic Status & $\begin{array}{c}-.518^{\star \star \star} \\
(.156)\end{array}$ & $\begin{array}{l}-.009 \\
(.012)\end{array}$ & $\begin{array}{l}-233^{\star *} \\
(115)\end{array}$ & $\begin{array}{l}.759^{\star \star \star} \\
(.318)\end{array}$ & $\begin{array}{l}.029 * \star \star \\
(.010)\end{array}$ & $\begin{array}{c}1273^{\star \star \star} \\
(424)\end{array}$ \\
\hline Number of observations & 7977 & 7978 & 7924 & 6324 & 7868 & 6036 \\
\hline $\begin{array}{l}\mathrm{R}^{2} \\
\text { Root MSE }\end{array}$ & $\begin{array}{c}.062 \\
6.908\end{array}$ & $\begin{array}{c}.136 \\
5.130\end{array}$ & $\begin{array}{c}.088 \\
7.222\end{array}$ & $\begin{array}{c}.335 \\
12.542\end{array}$ & $\begin{array}{l}.195 \\
.3901\end{array}$ & $\begin{array}{c}.262 \\
16604\end{array}$ \\
\hline
\end{tabular}

Source: Authors' analysis of National Education Longitudinal Study of 88 data.

Note: Estimations using OLS. Numbers in parenthesis below the coefficient are Huber-White standard errors that correct for clustering by school.

Values in brackets are F Tests of joint significance.

Statistically significant at 10 percent level on a two tail test; ** 5 percent level; ${ }^{\star \star \star} 1$ percent level. 
We begin by examining the effects of different types of high school courses on employment and wages immediately after graduation. Graduates who took many vocational courses did not work significantly more but nevertheless obtained higher wage rates and earned substantially more. Our regressions predict, for example, that a vocational concentrator with five occupational vocational courses (and 3 fewer academic courses) was paid 7.5 percent more per hour and earned 20 percent more than someone with no occupational vocational courses. Graduates who took extra academic courses in high school were, by contrast, less likely to work after high school, were paid slightly less per hour and earned less per month. Art, music and personal use courses had no effects on labor market outcomes. Rather surprisingly, introductory vocational courses had a positive effect on employment, wage rates (statistically significant) and on earnings in 1993, but computer courses had no effects.

Turning our attention to the effects of Minimum Competency Exams, and consistent with our earlier papers, we find once again that they had positive effects on earnings of recent high school graduates. The new finding is that these effects are, as we hypothesized, much larger for vocational concentrators than for non-concentrators. For example, state MCEs (and considering direct and indirect effects through course taking) had no effect on employment of non-vocational students, but they increased employment of vocational concentrators by 5.1 percent. Annual earnings in states with MCEs were 6.7 percent higher for non-vocational students and 9.6 percent higher for vocational concentrators. Wage rates were not significantly higher in MCE states for non-vocational students but were 5.5 percent higher for vocational concentrators.

Higher academic course graduation requirements had significant positive effects on wage rates. Holding total course graduation requirements and actual course taking patterns fixed, each one-unit increase in academic course requirements raises wage rates of non-concentrators by 1.5 percent and vocational concentrators by 1.8 percent. Policy impacts on concentrators were not significantly larger. Finally higher total course graduation requirements were associated with 
significantly lower wage rates. For instance, each one Credit unit increase in total graduation requirements was associated with wage rates being 0.7 percent lower $^{25}$.

Medium term effects of MCEs and Academic Requirements: We estimated models predicting employment (number of hours per week), logarithm of hourly wages and yearly earnings, all three for jobs held in 2000. Control variables are similar to the short-term effect models, with the addition of marital status and number of dependents, whether the respondent was a full-time or part-time student and the highest degree obtained at the time of the interview.

Attending high school in a MCE state continues (eight years after graduating) to have a strong positive relationship with wage rates and earnings. Non-concentrators who come from an MCE state were paid 3.9 percent more per hour and earned $\$ 2237$ more than people from nonMCE states. These long lasting effects imply that the large initial impact of MCEs on the reputation and perceived skill level of high school graduates did not quickly wear off. There are two possible explanations. The first explanation posits that the MCE signal was describing something real and long lasting about the worker-skill development induced by the existence of the MCE that were not captured by the short tests administered by the NELS88 study. The second possible explanation is that the improved information about the quality of young workers breaks down inaccurate negative stereotype and helps all recent high school graduates find jobs offering further training and opportunities for advancement. To check this second hypothesis we ran models predicting the type of jobs students obtained after graduation and the probability of receiving training from the employer. In both models the results confirm the hypothesis put forward: going to school in a MCE state reduces the probability of being in low skill jobs and increases the probability of receiving training sponsored by the firm.

The second conclusion is that MCEs continue to appear to have somewhat more positive effects on vocational students than on non-vocational students. Attending school in a MCE state appears to raise wage rates of Vocational concentrators by 7.7 percent. Nonconcentrators are paid only 3.7 percent extra when they come from a MCE state. Nonvocational students earn a statistically significant 7 percent more $(\$ 2095.00$ combining direct 
and indirect effects) when they are from a MCE state. Vocational concentrators earn about 4.8 percent (\$1435.00) more. Earnings gains are somewhat smaller for concentrators because work hours are lower for concentrators from MCE states.

Increases in the number of academic courses required to graduate have large positive effects on wage rates and earnings. Each one-unit increase in academic course requirements is associated with a $\$ 423$ increase in the yearly earnings and a 0.9 percent increase in wages of non-concentrators. Effects on wage rates are significantly less positive for vocational students. The total number of courses required to graduate has the opposite effect. Requiring more courses is associated with wage rates and earnings being significantly lower.

\section{Summary and Policy Implications}

In this paper we have analyzed the effects of tougher graduation requirements on course taking, learning, college attendance and post high school labor market outcomes for vocational concentrators and non-concentrators. Vocational students typically have weaker academic skills when they enter high school, so we hypothesized that tougher graduation requirements would have bigger effects on these students. Three different policies were evaluated: (1) state defined minimums for the total number of courses students must take and pass to get a high school diploma; (2) state defined minimums for the number of academic courses necessary to get a diploma and (3) minimum competency graduation tests. A summary of the results is presented in Table 5. 
Table 5

Estimation of Effects after Introduction Tougher Graduation Requirement

(Direct and Indirect Effects)

\begin{tabular}{|l|c|c|c|c|c|}
\hline & $\begin{array}{c}3 \text { Unit increase in } \\
\text { Total Course } \\
\text { Graduation } \\
\text { Requirements }\end{array}$ & \multicolumn{2}{|c|}{$\begin{array}{c}\text { 3 Unit increase in Academic } \\
\text { Course Graduation } \\
\text { Requirements }\end{array}$} & \multicolumn{2}{|c|}{$\begin{array}{c}\text { Introduction of Minimum } \\
\text { Competency Exams }\end{array}$} \\
\cline { 2 - 6 } & $\begin{array}{c}\text { Effects on all } \\
\text { students }\end{array}$ & $\begin{array}{c}\text { Effects on non- } \\
\text { vocational } \\
\text { students }\end{array}$ & $\begin{array}{c}\text { Effects on } \\
\text { vocational } \\
\text { concentrators }\end{array}$ & $\begin{array}{c}\text { Effects on non- } \\
\text { vocational } \\
\text { students }\end{array}$ & $\begin{array}{c}\text { Effects on } \\
\text { vocational } \\
\text { concentrators }\end{array}$ \\
\hline $\begin{array}{l}\text { Test scores } \\
\text { (\% of a GLE) }\end{array}$ & $-2.4 \%$ & $12.3 \%$ & $22.5 \%$ & $23.4 \%$ & $-7.6 \%$ \\
\hline $\begin{array}{l}\text { Obtaining associate } \\
\text { degree or higher }\end{array}$ & $-2.7 \%$ & $-0.7 \%$ & $-14.3 \%$ & $-2.7 \%$ & $5.4 \%$ \\
\hline $\begin{array}{l}\text { Obtaining bachelor } \\
\text { degree or higher }\end{array}$ & $-0.7 \%$ & $-6.1 \%$ & $-2.9 \%$ & $-14.4 \%$ & $5.1 \%$ \\
\hline Early wages & $-2.1 \%$ & $4.6 \%$ & $5.5 \%$ & $0.3 \%$ & $5.5 \%$ \\
\hline Early Earnings & $-0.9 \%$ & $3.6 \%$ & $3.8 \%$ & $6.7 \%$ & $9.6 \%$ \\
\hline Medium term wages & $-1.9 \%$ & $2.5 \%$ & $-1.7 \%$ & $3.7 \%$ & $7.7 \%$ \\
\hline $\begin{array}{l}\text { Medium term } \\
\text { Earnings }\end{array}$ & $-2.3 \%$ & $4.4 \%$ & $1.6 \%$ & $7.9 \%$ & $4.7 \%$ \\
\hline
\end{tabular}

Source: Authors' analysis of National Education Longitudinal Study of 88 data.

Clearly the policy with the least to recommend it is increases in the total number of full year courses required to graduate from high school. Holding the number of academic courses required to graduate constant, graduates educated in states with high total course graduation requirements do not take and pass more academic courses, do not learn more during high school and are paid less after high school (see table 5). ${ }^{26}$

Increasing the number of academic courses necessary to graduate has a number of positive effects on learning and labor market success. A three-credit increase in academic requirements results in a .23 GLE increase in learning for vocational concentrators and .12 GLE increase for non-vocational students. It is also associated with wages and earnings being 4 to 5 percent higher immediately after graduating from high school and 2 to 4 percent higher seven years after that. On the other hand, higher academic course requirements do not improve college 
attendance and completion rates and vocational concentrators are significantly less likely to get an associates or bachelors degree.

The policy with the most to recommend it is state minimum competency examinations. Test score gains of non-vocational students are .23 GLEs higher in MCE states. Vocational concentrators are about 11 percent more likely to go to college and 5 percent more likely to get a degree. Labor market outcomes are substantially better for both types of students in MCE states and vocational students benefit most of all. On the other hand, state MCEs reduce the share of graduates who do a vocational concentration. The vocational concentrators who meet the higher academic standards, however, benefit greatly from the signal that MCEs and tough academic course requirements sends to employers. Employers are in effect being told: "Vocational concentrators have both the occupational skills you seek and the academic skills you seek." The enhanced reputation of vocational concentrators improves their marketability. In our view, these findings tend to support the emphasis on combining rigorous academic coursework with specialization built around an occupational theme that characterizes the popular whole-school reform models for American upper-secondary education.

We began the paper by posing the question "Will the effort to raise academic achievement by toughening graduation requirements help or hurt the 40 percent of youth who seek full-time work immediately after high school and who never complete a single year of post-secondary education?" Studies of early labor market outcomes have found that computer courses and other occupation specific vocational courses have significant positive effects on earnings and wages while personal interest courses and academic courses do not. Most academic courses help students in college but hurt their chances of getting a good job (See table 4). If the tougher graduation requirements had forced a big reduction in number of students taking advanced vocational courses in high school, non-college bound students would have suffered reductions in their lifetime income. This did not happen, however. Students continued to take vocational courses at old levels and shifted into subjects like computers and health that were in high demand. The tougher academic requirements were met by giving up study halls, taking more 
academic courses and studying harder. High school graduation rates did not decline precipitously. Employers, who had been demanding higher academic standards, lived up to their end of the bargain by paying the graduates who met these higher standards better wages and offering them additional training opportunities. To many peoples surprise non-college bound students ended up benefiting from the reforms. 


\section{Bibliography}

Altonji, Joseph and Pierret, Charles (2001). "Employer Learning and Statistical Discrimination". Quaterly Journal of Economics. 116 (1), 313-350.

Becker, W. and Rosen, S. (1992). "The Learning Effect of Assessment and Evaluation in High School". Economics of Education Review. 11 (2), 107-118.

Betts, Julian (1998). "The Impact of Educational Standards on the Level and Distribution of Earnings". American Economic Review. 88 (1), 266-275.

Betts, Julian and Costrell, Robert M. (2001). "Incentives and Equity under Standards-Based Reform". Ravitch, D. (ed.), Brookings Papers on Education Policy. Washington, DC: The Brookings Institution.

Bishop, John (1992). "Impact of Academic Competencies on Wages, Unemployment and Job Performance". Carnegie-Rochester Conference Series on Public Policy. 37, 127-194. Bishop, John and Mane, Ferran (2001a). "The Impacts of Minimum Competency Exam Graduation Requirements on College Attendance and Early Labor Market Success of Disavantaged Students". Kornhaber, Mindy and Gary Orfield (Eds.) Raising Standards or Raising Barriers?, New York: the Century Foundation Press.

Bishop, John and Mane, Ferran (2001b). "The Impacts of Minimum Competency Exam Graduation Requirements on High School Graduation, College Attendance and Early Labor Market Success". Labour Economics, 8, 203-222..

Bishop, John and Mane, Ferran (2004). "The Impacts of Career-Technical Education on High School Completion and Labor Market Success". Economics of Education Review, 19, 333-349.

Bishop, John; Moriarty, Joan; and Mane, Ferran. (2000). ."Diplomas for Learning: not seat time".

Economics of Education Review. 19, 333-349.

Bishop, John; Mane, Ferran; Bishop, Michael; and Moriarty, Joan. (2001). "The Role of End-ofCourse Exams and Minimum Competency Exams in Standards-Based Reforms". Ravitch, D. (ed.), Brookings Papers on Education Policy. Washington, DC: The Brookings Institution.

Campbell, Paul B.; Basinger, Karen S.; Dauner, Mary Beth; and Parks, Marie A. (1986).

"Outcomes of Vocational Education for Women, Minorities, the Handicapped, and the Poor." Columbus: The National Center for Research in Vocational Education, The Ohio State University.

Campbell, Paul B.; Elliot, Jack; Laughlin, Suzanne and Seusy, Ellen. (1987). "The Dynamics of Vocational Education Effects on Labor Market Outcomes." Columbus: The National Center for Research in Vocational Education, The Ohio State University. 
Commission on the Skills of the American Workforce (1990). America's Choice: High Skills or Low Wages!. Rochester, NY: National Center on Education and the Economy.

Costrell, Robert M. (1994). "A Simple Model of Educational Standards". American Economic Review. 84 (4), 956-971.

Farber, Henry and Gibbons, Robert (1996). "Learning and Wage Dynamics". Quaterly Journal of Economics. 111 (4), 1007-1047.

Johnson, Jean; Duffett, Ann; Foleno, Tony; Foley, Patrick; and Farkas, Steve (2001). "Reality Check 2001", Education Week, February 21, S1-S8.

Lillard, Dean and DeCicca, Phillip (2001). "Higher Standards, More Dropouts? Evidence within and across Time", Economics of Education Review, 20 (5), 459-473..

Mane, Ferran (1999). "Trends in the payoff to academic and occupation-specific skills". Economics of Education Review. 18, 417-437.

Murnane, Richard and Levy, Frank. (1996). Teaching the New Basic Skills: Principles for Educating Children to Thrive in a Changing Economy. New York: The Free Press.

Murnane, Richard; Willet, John; and Levy, Frank. (1995). "The Growing Importance of Cognitive Skills in Wage Determination". Review of Economics and Statistics, 77 (2), 251-266.

Murnane, Richard; Willet, John; Duhaldeborde, Yves; and Tyler, John H. (2000). "How Important Are the Cognitive Skills of Teenages in Predicting Subsequent Earnings?" Journal of Policy Analysis and Management 19 (4), 547-568.

National Commission on Excellence in Education (1983). A Nation at Risk: The Imperative for Educational Reform. Washington, DC: Government Printing Office.

William T. Grant Foundation Commission on Work, Family, and Citizenship (1988). The Forgotten Half: Pathways to Success for America's Youth and Young Families. Washington, DC. 


\section{Endnotes}

${ }^{1}$ Commission on the Skills of the American Workforce, 1990; National Commission on Excellence in Education, 1983; William T. Grant Foundation, 1988.

${ }^{2}$ We are aware that it might be rather difficult for a non-American reader to fully understand some concepts used in this paper regarding the American educational system. We have tried to avoid major problems detailing some of them. For those still interested in more information, we recommend to download from http://www.oecd.org/els/edu/TIEW/index.htm the Country Note for United States where the reader will find an overview of the system and a discussion of its main problems.

${ }^{3}$ High school students in the US have a high level of discretion in the election of courses they want to take. In addition, in a typical high school, it is normal to have the same course taught at different levels of difficulty.

${ }^{4}$ In the US, State governments have a lot of freedom to set educational regulations. It is then possible to find different educational policies in different States.

${ }^{5}$ For a detailed review of these policies intended to address the problem of learning standards along with some others not considered in this paper see Bishop, Mane, Bishop and Moriarty (2001:272-279).

${ }^{6}$ Full-time full-year courses have 120 to 150 hours of instruction time. Many high schools set higher course graduation requirements than the minimum established by state government.

${ }^{7}$ High school is a four year programme of study. The sequence is freshman ( $9^{\text {th }}$ grade- 15 years old), sophomore $\left(10^{\text {th }}\right.$ grade-16 years old), junior $\left(11^{\text {th }}\right.$ grade- 17 years old $)$ and senior $\left(12^{\text {th }}\right.$ grade-18 years old).

${ }^{8}$ MCEs don't normally set a high standard (over $10^{\text {th }}$ grade proficiency). Although in some states failure rates for students taking the test for the first time can be as high as $50 \%$, many students eventually manage to pass them and failure rates are between 5 to $15 \%$.

${ }^{9}$ There is a small, but interesting, literature on educational standards. See for instance Becker and Rosen (1992); Costrell (1994); Betts (1998); and Betts and Costrell (2001).

${ }^{10}$ When a student moved to another state between 10th and 12th grade an average of the MCE variables was used. Then the MCE variable can have three values: 1,0 or 0.5 , this last one representing moving out from or in to an MCE state. When information on the state was not available for 10th grade, residence in 12th grade was used and if that was missing as well, 8th grade residence was used. None of the states changed their policies during the 1990 to 1992 time period.

${ }^{11}$ States without state-wide minimum course graduation requirements were assigned a value of 13-the lowest minimum total credit requirement for the states with a requirement and a control variable was included in the models.

12 The three largest groups of courses included in our "Personal Interest" category are visual and performing arts, health and physical education. The category also includes courses in interpersonal skills, leisure and recreation activities, citizenship/civic activities, military sciences and technologies, library sciences, theology and life skills taken from the detailed course codes available in the restricted data set.

${ }^{13}$ Since computer skills are necessary in every occupation, computer courses were counted towards the three minimum credits regardless of the occupational field being pursued.

14 At the student-family level controls were included for: the student's grade point average in 8th grade, an average of test scores in English, mathematics, science and social studies in 8th grade, whether they took remedial courses in 8th grade, whether they took advanced courses, TV and homework hours, reading for pleasure, an indicator for being handicapped, socio-economic status of the student's family, logarithm of the number of books in the home, parent involvement index, family size, marital and parental status in 8th grade, locus of control index, self esteem index and hours working for pay during 8th grade (and it's square), an index for smoking in 8th grade, dummies for race, ethnicity and religion, dummies for 4 Census regions and rural, suburban and urban residence. Regarding the school attended we included: numbers of students enrolled in 10th grade and it's square, average teacher salary, student-teacher ratio, percent of students eligible for free lunch, the ethnic breakdown of the student body, the average socio- 
economic status and 8th grade test scores of students at the school. We also included control variables measuring the following characteristics of the state: unemployment rate, mean weekly wage in retailing and manufacturing, ratio of the high school graduate earnings to the high school dropout earnings in 1989 , ratio of college graduate earnings to high school graduate earnings in 1989, ratio of tuition at four year public colleges to the weekly earnings in retailing and dummies for 4 Census regions. All our estimates report Huber-White robust standard errors that account for the clustering of students within schools and states, which deals with the problem of the correlation of errors generated by the clusterbased sampling frame.

${ }^{15}$ The GPA is an unweighted average of teacher grades in all courses.

${ }^{16}$ Tests were centrally defined by the survey staff, so all students took the same tests. Note that the variable measures increases-decreases in the test score, not the absolute value. Tests were standardized to have a mean of 50 and a standard deviation of 10 .

${ }^{17}$ In order to prevent the measurement error in the test scores from biasing the results, the lagged value of the test whose gain score was being predicted did not appear on the right hand side of the regression. When the gains on individual tests were being predicted, however, the student's scores on the other three 8th grade tests were included as control variables.

18 A grade level equivalent is the average improvement in achievement that occurs over the course of a year in school. The coefficients were translated into grade level equivalent (GLE) effects by dividing by an estimate of the test score gain during one year of school. GLE's were calculated by dividing the test score gains given in row 2 by four. Thus a GLE in science was 1.95 points (7.42/4), so the effect of one additional year of academic course taking was $(.385 / 1.95)=.197$ GLEs for science.

${ }^{19}$ Other statistically significant determinants of 8th to 12th grade learning: males learned .46 of a grade level equivalent more than females and African-Americans learned .47 GLEs less than whites. Learning gains were also greater for students high on the read for fun index and high on the internal locus of control index and for students who watched a great deal of TV in 8th grade. Learning gains were greater when pupil teacher ratios were low, at schools serving high SES students and at schools where entering students had low 8th grade test scores.

${ }^{20}$ Multiplying column 4 in table 1 by the corresponding values of column 6 in table 2 . More specifically, (($\left.0.001 * 0.145)+(0.031 *-0.053)+(0.019 * 0.243)+\left(0.111^{*} 0.373\right)+(0.151 * 0.021)\right)$.

${ }^{21} 0.079 /\left(0.25^{\star} 7.9\right)$, where 0,25 converts the 4 year period in 1 year period and 7.9 is the mean increase over the 4 year span.

${ }^{22}$ This result is different from some of our earlier papers because the sample is not the same and also because we include in this paper New York as an MCE state.

23 With respect the results for the control variables, students with the highest college enrolment rates attended schools serving high SES communities, schools that paid their teachers more than average, small high schools and Catholic high schools and lived in communities with high unemployment rates. With respect to the individual control variables, few of the findings are surprising. Holding other characteristics constant, those who attended college tended to come from small, intact, high SES families, tended to be Asians or African-American rather than white, to have a Catholic or Jewish religion rather than Protestant, or no religion, high on the internal locus of control index, non-smokers who spent many hours doing homework in 8th grade.

${ }^{24}$ The first exception to that generalization was the inclusion of controls for current and past college attendance: The number of semesters of full-time college attendance during the period from fall 1992 to Spring 1994, number of semesters of part-time college attendance during that same period, the number semesters attending a two year institution full-time and the number of semesters of part-time attendance at a two year institution. The second exception was the inclusion of controls for "Ever dropped out," "Obtained a General Education Degree (GED)," "graduated early" and, for late graduates, "the length of the delay in graduation." Notes that as in the regressions we control for when students graduated from high school and whether they attended college, we are measuring the short run effects of graduation requirements on labor market success net of effects that operate through the probability of attending college. 
${ }^{25}$ Other student characteristics associated with significantly lower earnings or lower wage rates were: current attendance at college, female, African American, Asian, handicapped, rural location, Northeastern location, many siblings, and attending a school with a high incidence of free lunch. Earnings were higher for students who had worked for pay in $8^{\text {th }}$ grade, who had an internal locus of control and high self esteem and for students with parents who set tighter limits on behavior in $8^{\text {th }}$ grade.

${ }^{26}$ Variations in elective and personal interest courses account for most of the variance in the state set minimums for total numbers of courses required to graduate. No state requires students to take more than 14 academic courses. Consequently, the total number of courses required to graduate can be lowered without reducing the number of required academic courses. Indeed a state could reduce total requirements while increasing academic requirements. 